\title{
Pengaruh Physical Distancing dan Strategi Pemasaran Terhadap Keberlanjutan Usaha Pedagang Pada Saat Pandemi COVID-19 Di Lokasi Binaan Munjul Jakarta Timur
}

\author{
Nurlela Runiati Sihombing ${ }^{1}$, Nurminingsih ${ }^{2}$, Bachtar Bakrie ${ }^{3}$ \\ Program Studi Administrasi Bisnis Program Magister Universitas Respati Indonesia \\ email:leto270610@yahoo.com,nings@urindo.ac.id,bachtarbakrie@yahoo.com
}

\begin{abstract}
ABSTRAK
Lokasi Binaan Munjul ditetapkan melalui Keputusan Kepala Suku Dinas Koperasi, Usaha Kecil dan Menengah serta Perdagangan Kota Administrasi Jakarta Timur Nomor 10/2017 tentang Penetapan Lokasi Binaan Usaha Mikro/Pedagang Kaki Lima di Kota Administrasi Jakarta Timur tanggal 27 Oktober 2017. Penelitian ini mengkaji permasalahan faktor keberlanjutan usaha pedagang pada saat pandemi covid-19 di Lokasi Binaan Munjul. Tujuan penelitian ini ingin mengetahui pengaruh penerapan Physical Distancing dan Strategi Pemasaran terhadap Keberlanjutan Usaha Pedagang pada saat Pandemi Covid-19 di Lokasi Binaan Munjul Jakarta Timur. Pendekatan penelitian ini termasuk paradigma penelitian kuantitatif dengan menggunakan metode pengambilan sampel menggunakan kuesioner sebagai instrumen utama untuk mengumpulkan data. Populasi penelitian ini adalah pedagang di Lokasi Binaan Munjul yang tetap berjualan pada saat pandemi covid19 dan teknik pengambilan sampel menggunakan sampel jenuh (total sampling) yang diambil sebanyak 122 orang sebagai sampel penelitian dan menggunakan Analisis data SEM PLS-3. Hasil perhitungan untuk uji hipotesis path Coefficients dapat disimpulkan bahwa Physical Distancing berpengaruh positif signifikan terhadap Strategi Pemasaran, Physical Distancing berpengaruh positif signifikan terhadap Keberlanjutan Usaha, Strategi Pemasaran berpengaruh positif signifikan terhadap Keberlanjutan Usaha, Physical Distancing dan Strategi Pemasaran berpengaruh tidak langsung terhadap Keberlanjutan Usaha. Kesimpulannya Keberlanjutan Usaha dipengaruhi oleh penerapan Physical Distancing dan Strategi Pemasaran.
\end{abstract}

\section{Kata Kunci : Physical Distancing, Strategi Pemasaran dan Keberlanjutan Usaha}




\begin{abstract}
The location of Munjul's Assistance is determined through Decree of the Head of the Office of Cooperatives, Small and Medium Enterprises and East Jakarta Administration City Trade Number 10/2017 concerning Determination of Locations for Micro Businesses / Street Vendors in the Administrative City of East Jakarta on 27 October 2017. This research examines the problem of factors. the sustainability of traders' businesses during the Covid-19 pandemic at the Munjul Assisted Location. The purpose of this study was to determine the effect of the application of Physical Distancing and Marketing Strategies on the Business Sustainability of Traders during the Covid-19 Pandemic in the Munjul Assisted Location, East Jakarta. This research approach includes a quantitative research paradigm using a sampling method using a questionnaire as the main instrument for collecting data. The population of this study were traders at the Munjul Assisted Areas who continued to sell during the Covid-19 pandemic and the sampling technique used was saturated samples (total sampling) which were taken as many as 122 people as the research sample and using SEM PLS-3 data analysis. The results of the calculation for the path coefficients hypothesis test can be concluded that physical distancing has a significant positive effect on marketing strategy, physical distancing has a significant positive effect on business sustainability, marketing strategy has a significant positive effect on business sustainability, physical distancing and marketing strategy has an indirect effect on business sustainability. In conclusion, business sustainability is influenced by the application of physical distancing and marketing strategies.
\end{abstract}

Keywords: Physical Distancing, Marketing Strategy and Business Sustainability. 


\section{PENDAHULUAN}

Perekonomian Indonesia mengalami pertumbuhan dan tercatat pada Kuartal I Tahun 2020 sebesar 4,7\% dimana secara makro ekonomi Indonesia akan terus menurun sehingga perkonomian di Indonesia dikatakan menurun drastis (www.inews.id/Kamis, 9 April 2020). Penurunan ekonomi dikarenakan adanya wabah yang terjadi di seluruh dunia termasuk Indonesia. Dampak adanya wabah Covid-19 terjadi di semua sektor mulai dari sektor publik, sosial dan bisnis. Menyikapi pandemi Covid-19 ini maka berbagai kebijakan mulai dimunculkan untuk memutus penyebaran Covid-19. Mulai dari penerapan work from home, social distancing dan physical distancing, sampai diberlakukan Pembatasan Sosial Berskala Besar (PSBB).

Kebijakan tersebut sedikit banyak berpengaruh pada kegiatan bisnis di pasar Lokasi Binaan Munjul dimana terjadi adanya penurunan jumlah pelanggan dan penuruanan omset pada beberapa pedagang. Penerapan jaga jarak atau physical distancing di pasar menjadi perhatian khusus karena pasar merupakan interaksi antara pedagang dan penjual yang memungkinkan terjadinya kontak fisik, hal tersebut karena ruang pasar yang sempit, penuh dengan pedagang dan banyak barang yang diperdagangkan.

Akibat dari kondisi tersebut maka metode pemasaran pada saat pandemi Covid-19 harus diimbangi dengan berjualan secara online, sebab untuk melaksanakan pemasaran online secara keseluruhan tidak memungkinkan karena beberapa faktor. Faktor kebiasaan seperti pada kondisi normal dimana penjualan dilaksanakan secara konvensional dengan pertemuan langsung antara penjual dan pembeli sebagaimana layaknya pasar tradisional di seluruh Indonesia.

\section{KAJIAN TEORI}

\section{Physical Distancing}

Physical Distancing untuk menghindari penyebaran virus corona yang lebih luas yang dilakukan dengan menjaga jarak fisik namun orang-orang tetap bisa berinteraksi secara sosial sesuai jarak yang dianjurkan yaitu minimal 1 (satu) meter. Physical distancing di pasar ini dalam melaksanakan transaksi jual beli adalah sebagai berikut :

1. Pengaturan jumlah pengunjung

2. Jarak antrian 1 meter

3. Pengontrolan pembelian bahan pokok dan barang penting

4. Pembersihan secara rutin dengan disinfektan.

\section{Strategi Pemasaran}

Strategi pemasaran pada
dasarnya adalah rencana yang menyeluruh, terpadu dan menyatu di bidang pemasaran, yang memberikan panduan tentang kegiatan yang akan dijalankan untuk dapat tercapainya tujuan pemasaran suatu perusahaan. Dengan kata lain, strategi pemasaran adalah serangkaian tujuan dan sasaran, kebijakan dan aturan yang memberi arah kepada usaha-usaha pemasaran perusahaan dari waktu ke waktu, pada masing-masing tingkatan dan acuan serta alokasinya, terutama sebagai tanggapan perusahaan dalam menghadapi lingkungan dan keadaan persaingan yang 
selalu berubah. strategi pemasaran adalah rangkaian tujuan dan sasaran serta kebijakan dan aturan-aturan yang memberi arah kepada pedagang pasar dalam menghadapi lingkungan dan keadaan persaingan yang selalu berubah yang indikatornya adalah strategi produk, strategi harga, strategi tempat dan strategi promosi.

\section{Keberlanjutan Usaha}

Keberlanjutan usaha adalah upaya dan kemampuan para pedagang di pasar untuk meminimalisir dampak negatif Covid-19 bagi kegiatan bisnis dengan cara mempertahankan berjalannya usaha yang indikatornya adalah permodalan, sumber daya manusia, produksi, dan pemasaran.

\section{METODE PENELITIAN}

Penelitian ini termasuk jenis penelitian kuantitatif. Penelitian ini dilakukan di Lokasi Binaan Munjul yang beramat di Jalan Raya Munjul Kelurahan Munjul Kecamatan Cipayung Jakarta Timur. Sampel dalam penelitian ini berjumlah

122 responden.

Pengumpulan data diperoleh melalui data primer dan data sekunder. Analisis data dan pengujian hipotesis menggunakan Structural Equation Model (SEM) dengan menggunakan software partial least square (PLS). Adapun tahap-tahap pengujiannya outer dan inner model meliputi uji Convergent Validity, Discriminant Valdity, Composite Reliability, $R$-square dan path koefisien.

\section{HASIL PENELITIAN DAN PEMBAHASAN}

Berdasarkan penelitian yang telah dilakukan outer model penelitian adalah sebagai berikut :

\section{Gambar 1. Outer Model}

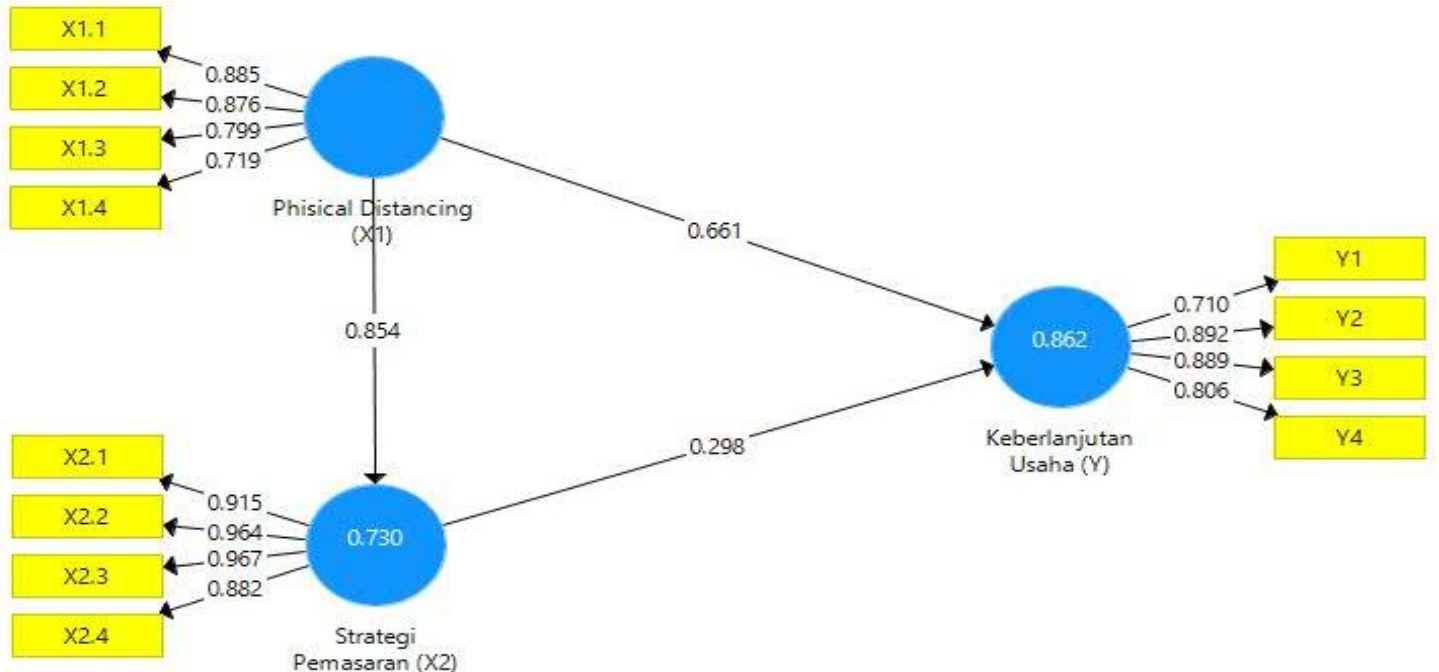

Sumber : SmartPLS, 2020

Berdasarkan hasil uji validitas variabel Physical Distancing, Strategi Pemasaran dan Keberlanjutan Usaha didapatkan hasil bahwa 21 item pernyataan dinyatakan valid karena nilai outer loading $>0,5$. Hal tersebut berarti butir-butir pernyataan dalam variabel physical distancing, strategi pemasaran, 
dan keberlanjutan usaha dinyatakan valid dan layak digunakan sebagai instrumen penelitian.

Uji reliabilitas menunjukkan sejauh mana suatu alat ukur yang dapat memberikan hasil yang relative sama apabila dilakukan pengukuran kembali pada subyek yang sama. Uji reliabilitas dapat dilihat pada Tabel 1 sebagai berikut:

Tabel 1

\section{Uji Reliabilitas}

\begin{tabular}{|c|c|c|c|}
\hline & $\begin{array}{c}\text { Composite } \\
\text { Realibility }\end{array}$ & $\begin{array}{c}\text { Cronbach's } \\
\text { Alpha }\end{array}$ & $\begin{array}{c}\text { Average variance } \\
\text { extracted (AVE) }\end{array}$ \\
\hline $\begin{array}{c}\text { Physical } \\
\text { Distancing (X1) }\end{array}$ & 0.893 & 0.842 & 0.677 \\
\hline $\begin{array}{c}\text { Strategi } \\
\text { Pemamsaran } \\
\text { (X2) }\end{array}$ & 0.964 & 0.950 & 0.869 \\
\hline $\begin{array}{c}\text { Keberlanjuntan } \\
\text { Usaha (Y) }\end{array}$ & 0.896 & 0.844 & 0.685 \\
\hline
\end{tabular}

Sumber : Data diolah SEM - SmartPLS

Hasil pengolahan uji reliabilitas pada variabel physical distancing, strategi pemasaran dan keberlanjutan usaha didapatkan nilai Composite Reliability (CR) untuk semua konstruk lebih besar dari 0,7 yang menunjukkan bahwa semua konstruk pada model diestimasi memenuhi kriteria discriminant validity. Selanjutnya Menurut Hair et., al (1998), direkomendaskan nilai Average Variance Extracted (AVE) untuk semua konstruk harus lebih besar dari 0,5. Berdasarkan tabel 1 menunjukkan bahwa nilai akar dari $A V E$ untuk setiap konstruk adalah lebih besar dari 0,5 atau lebih. Dengan demikian hasil pengujian Average Variance Extracted (AVE) semua reliable. Berdasarkan hasil seluruh uji instrument dari uji validitas dan reliabilitas dinyatakan bahwa semua butir pernyataan memenuhi persyaratan untuk dipakai dalam instrument penelitian. 
Selanjutnya Pengujian Model Struktural (Inner Model)

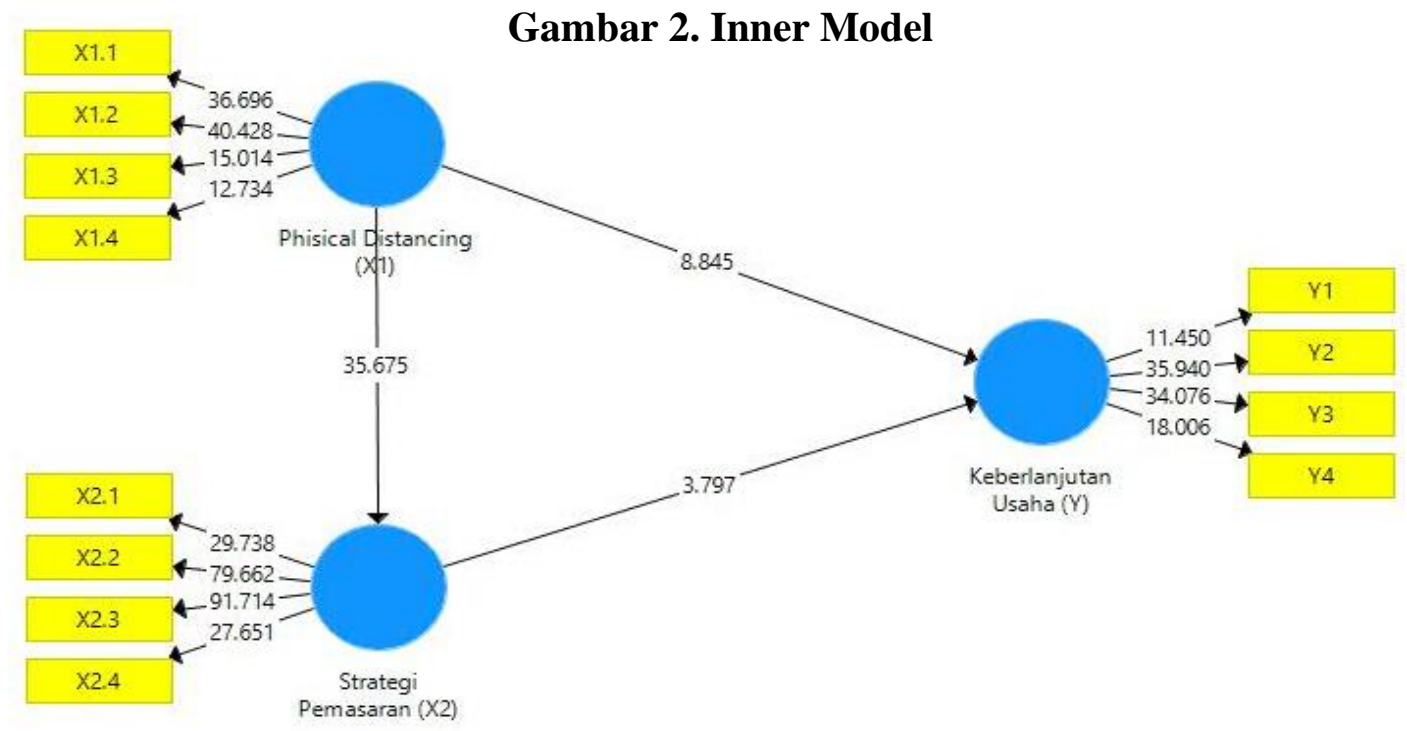

Sumber : SmartPLS, 2020

Hasil pengolahan data variabel dan keberlajutan usaha dapat dilihat pada physical distancing, strategi pemasaran tabel 2 dibawah ini:

\section{Tabel 2}

\section{Hasil Uji Hipotesis}

\begin{tabular}{|l|c|c|c|c|c|}
\hline & $\begin{array}{c}\text { Original } \\
\text { Sample (O) }\end{array}$ & $\begin{array}{c}\text { Sample } \\
\text { Mean (M) }\end{array}$ & $\begin{array}{c}\text { Standard } \\
\text { Deviation } \\
\text { (STDEV) }\end{array}$ & $\begin{array}{c}\text { T Statistics } \\
(\mid \mathrm{O} / \mathrm{STDEV})\end{array}$ & Sig \\
\hline $\begin{array}{l}\text { Physical Distancing } \\
\text { (X1) -> Strategi } \\
\text { Pemasaran (X2) }\end{array}$ & 0.854 & 0.857 & 0.022 & 38.62 & 4 \\
\hline $\begin{array}{l}\text { Phisical Distancing (X1) } \\
\text { Keberlanjutan Usaha (Y) }\end{array}$ & 0.661 & 0.663 & 0.074 & 8.903 & 0.000 \\
\hline $\begin{array}{l}\text { Strategi Pemasaran (X2) } \\
\text { Keberlanjutan Usaha (Y) }\end{array}$ & 0.298 & 0.296 & 0.078 & 3.818 & 0.000 \\
\hline $\begin{array}{l}\text { Phisical Distancing (X1)-> } \\
\text { Strategi Pemasaran (X2)-> } \\
\text { Keberlanjutan Usaha } \\
\text { (Y) }\end{array}$ & 0.254 & 0.254 & 0.069 & 3.690 & 0.000 \\
\hline
\end{tabular}

Sumber : Data diolah SEM-Smart-PLS 
1) Pembuktian Hipotesis 1 : Pembuktian Physical Distancing (X1) berpengaruh terhadap Strategi Pemasaran (X2)

Tabel 2 menunjukkan hasil Original Sample $=0,854$, T Statistic $=38,624$, $\mathrm{P}$ Values $=0,000(<0,05)$. Hal ini menunjukkan bahwa pengaruh antara physical distancing terhadap strategi pemasaran adalah signifikan. Demikian H1 dalam penelitian ini diterima. Artinya physical distancing berpengaruh signifikan terhadap strategi pemasaran.

2) Pembuktian Hipotesis 2 : Physical Distancing berpengaruh signifikan terhadap Keberlanjutan Usaha Tabel 2 menunjukkan hasil Original Sample $=0,661$, T Statistic $=8,903$, $\mathrm{P}$ Values $=0,000(<0,05)$. Hal ini menunjukkan bahwa pengaruh antara physical distancing terhadap keberlanjutan usaha adalah signifikan. Demikian H2 dalam penelitian ini diterima. Artinya physical distancing berpengaruh signifikan terhadap strategi pemasaran.

\section{3) Pembuktian 3 : Strategi} Pemasaran berpengaruh signifikan terhadap Keberlanjutan Usaha

Tabel 2 menunjukkan hasil Original Sample $=0,298$, T Statistic $=3,818$, $\mathrm{P}$ Values $=0,000(<0,05)$. Hal ini menunjukkan bahwa pengaruh antara strategi pemasaran terhadap keberlanjutan usaha adalah signifikan. Demikian H3 dalam penelitian ini diterima. Artinya strategi pemasaran berpengaruh signifikan terhadap keberlanjutan usaha.

4) Pembuktian 4 : Physical Distancing dan Strategi Pemasaran berpengaruh tidak langsung terhadap Keberlanjutan Usaha Tabel 2 menunjukkan hasil Original Sampel $=0,254, \mathrm{~T}$ Statistic $=3,690 \mathrm{P}$ Values $=0,000(<0,05)$. Hal ini menunjukkan bahwa pengaruh Physical distancing dan Strategi Pemasaran dengan Keberlanjutan Usaha adalah signifikan. Demkian H4 dalam penelitian ini diterima. Artinya physical distancing dan strategi pemasaran berpengaruh terhadap keberlanjutan usaha.

\section{PEMBAHASAN}

\section{Physical Distancing berpengaruh terhadap Strategi Pemasaran}

Hasil penelitian ini sesuai dengan Surat Edaran Kepala Dinas Nomor 79/SE/2020 tentang Himbauan Teknis Antisipasi dan Pencegahan Penyebaran Corona Virus Disease (Covid-19) pada Area Lokasi Binaan dan Lokasi Sementara Kuliner di Wilayah Provinsi DKI Jakarta. Dan penelitian yang telah dilakukan terdahulu yaitu Fidah Syadidurrahmah (2020), Fika Muntahaya (2020) dkk tentang pengetahuan terkait Physical Distancing memiliki hubungan dengan perilaku Physical Distancing.

\section{Physical Distancing berpengaruh terhadap Keberlanjutan Usaha}

Pedagang di Lokasi Binaan Munjul pada saat pandemi covid-19 
masih bertahan dalam usahanya karena memiliki modal, sumber daya manusia, produksi dan pemasaran yang tepat sasaran ke pembeli. Hal ini sesuai dengan penelitian terdahulu oleh Ali Shandy Mulya (2017) tentang faktor yang mempengaruhi keberlanjutan perusahaan yaitu salah satunya dukungan aset (modal) dalam keberlanjutan usaha.

\section{Strategi Pemasaran berpengaruh terhadap Keberlanjutan Usaha}

Strategi Pemasaran merupakan cerminan 4 (empat) indikator yaitu strategi produk, strategi harga, strategi tempat dan strategi promosi. Pedagang yang saat masa pandemi covid-19 memilih tetap berjualan memiliki strategi pemasaran untuk keberlanjutan usahanya.

Hasil penelitian ini sesuai dengan penelitian yang telah dilakukan terdahulu oleh Fajar B. Hirawan dan Akita A. Verselita (2020) yang membuktikan bahwa pangan lebih banyak dibutuhkan pada saat pandemi covid-19 sehingga perlu strategi pemasaran untuk keberlanjutan usaha. Hal tersebut juga dibuktikan dengan jenis usaha yang ada di Lokasi Binaan Munjul yaitu didominasi oleh usaha pangan sebanyak $79 \%$. Sehingga pedagang harus memiliki strategi produk apa yang harus dijual di Lokasi Binan Munjul.

\section{Physical Distancing dan Strategi Pemasaran berpengaruh terhadap Keberlanjutan Usaha}

Hubungan antara Physical distancing (X1) dan Strategi Pemasaran (X2) dengan Keberlanjutan Usaha (Y) adalah positif. Hasil penelitian ini sesuai dengan hasil penelitian terdahulu yang telah dilakukan oleh Sangputri Sidik, dkk (2020) bahwa adanya wabah covid19 berdampak pada keberlanjutan usaha pedagang.

\section{KESIMPULAN DAN SARAN}

\section{Kesimpulan}

Berdasarkan hasil analisis SEM (Structural Equation Modeling) dan pembahasan yang telah dilakukan dalam penelitian ini, maka terdapat beberapa kesimpulan sebagai berikut :

1. Hasil analisis data menunjukkan bahwa Physical

Distancingberpengaruh positif signifikan terhadap Strategi Pemasaran. Physical Distancing merupakan cerminan 4 (empat) indikator yaitu pengaturan jumlah pengunjung, jarak antrian 1 meter, pengontrolan pembelian bahan pokok dan barang penting serta pembersihan secara rutin dengan disinfektan.

2. Hasil analisis data menunjukkan bahwa Physical Distancing (X1) berpengaruh positif signifikan terhadap Keberlanjutan Usaha (Y). Hal ini menunjukkan keberlanjutan usaha merupakan cerminan 4 (empat) indikator yaitu permodalan, sumber daya manusia, produksi, dan pemasaran.

3. Hasil analisis data menunjukkan bahwa Strategi Pemasaran (X2) berpengaruh positif signifikan terhadap Keberlanjutan Usaha (Y). Hal ini menunjukkan strategi pemasaran merupakan cerminan 4 (empat) indicator yaitu strategi produk, strategi harga, strategi tempat dan strategi promosi. 
4. Hasil analisis data menunjukkan bahwa Physical Distancing (X1) dan Strategi Pemasaran (X2) berpengaruh tidak langsung terhadap Keberlanjutan Usaha (Y). Hal ini menunjukkan bahwa pengaturan jumlah pengunjung, jaga jarak, pengontrolan bahan pangan dan pembersihan secara rutin, dan strategi pemasaran berpengaruh tidak langsung terhadap keberlanjutan usaha.

\section{Saran}

1. Perlu dilakukan evaluasi terhadap pembersihan di Lokasi Binaan Munjul oleh petugas.
2. Perlu strategi promosi yang dapat diterapkan pada masa covid-19 dengan melalui media sosial sehingga cara-cara saat ini yang konvensional dapat ditingkatkan lagi mengingat kondisi sekarang ini.

3. Untuk keberlanjutan usaha agar pedagang menambahkan modal usahanya.

4. Agar Lokasi Binaan Munjul perlu dilakukan evaluasi pembersihan serta bagi pedagang agar menerapkan strategi berjualan online dan meningkatkan modal usahanya supaya dapat berkelanjutan usahanya selama pandemi covid-19. 


\section{DAFTAR PUSTAKA}

Abdillah., W dan Jogiyanto. 2009. Partial Least Square (PLS) Alternatif SEM Dalam Penelitian Bisnis . Penerbit Andi: Yogyakarta. Hal 262.

Assauri, Sofjan. 2007. Manajemen Pemasaran Dasar, Konsep dan Strategi, PT Raja Grafindo Persada, Jakarta

Achmad, S. Ruky. 2003. Kualitas Sumber Daya Manusia. Jakarta: PT Gramedia Pustaka Utama

Achmad Suryana. 2003. Kapita Selekta,Evolusi Pemikiran Kebijakan Ketahanan Pangan. Yogyakarta :BPFE-Yogyakarta. Aswatini, dkk. (2004). Ketahanan Pangan, Kemiskinan

Arikunto, Suharsimi. 2006. Prosedur Penelitian Suatu Pendekatan Praktik Edisi Revisi. Jakarta: Rineka Cipta.

A Muri Yusuf. 2013. Metode Penelitian Kualitatif, Kuantitatif dan Penelitian Gabungan (Pertama). Jakarta: Renika Cipta

Daniel Aldrich, 2020, menyoroti makna social distancing, https://www.kompas.com/tren/rea d/2020/03/30/071700465/pandan gan-para-ahli-soal-social- distancing-dan-physicaldistancing

Fajri, 2013, Analisis Kinerja Pendapatan Asli Daerah Kabupaten Bungo https://webcache.googleuserconte nt.com/search?q=cache:uxgscs94 zkcJ:https://onlinejournal.unja.ac.id/mankeu/article/ download $/ 4051 / 2938 /+\& c d=$ $\underline{12 \& \mathrm{hl}=\mathrm{id} \& \mathrm{ct}=\mathrm{clnk} \& \mathrm{gl}=\mathrm{id}}$

Ghozali, Imam. 2011. “Aplikasi Analisis Multivariate Dengan Program SPSS". Semarang: Badan Penerbit Universitas Diponegoro.

Kotler, Philip, 2006, Manajemen Pemasaran, Jilid 1, Terjemahan Hendra Teguh dkk, Jakarta: PT. Prenhalindo

Kelly Robbins, 2026, How To Build the Endurance You Need to Achieve Your Business Goals, https://www.goalsontrack.com/bl og/2016/05/18/how-to-build-theendurance-you-need-to-achieveyour-business-goals/

Pandji, Anoraga. 1997. Manajemen Bisnis. Jakarta: Rineka Cipta.

Peraturan Pemerintah (PP) No. 21/2020 tentang Pembatasan Sosial Berskala Besar ( $\underline{\text { PSBB }})$. 
Peraturan Gubernur Daerah Khusus Ibukota Jakarta Nomor 33 Tahun 2020 Tentang Pelaksanaan Pembatasan Sosial Berskala Besar Dalam Penanganan Corona Virus Disease 2019 (Covid-19) Di Provinsi Daerah Khusus Ibukota Jakarta

Sugiyono. 2013. Metode Penelitian Pendidikan Pendekatan Kuantitatif, Kualitatif, dan R\&D. Bandung: Alfabeta.

Sugiyono, 2015,. Metode Penelitian Kombinasi (Mix Methods). Bandung: Alfabeta.

Surat Edaran Kepala Dinas Nomor 79/SE/2020 tentang Himbauan Teknis Antisipasi dan Pencegahan Penyebaran Corona Virus Disease (Covid-19) pada Area Lokasi Binaan dan Lokasi Sementara Kuliner di Wilayah Provinsi DKI Jakarta.

Undang-Undang Republik Indonesia Nomor 20 Tahun 2008 Tentang Usaha Mikro, Kecil, Dan Menengah
WHO. Report of the WHO-China Joint Mission on Coronavirus Disease 2019 (COVID-19). Geneva: World Health Organization; 2020.

Wasisto Raharjo Jati, 2012, Teosofi: Jurnal Tasawuf dan Pemikiran Islam Volume 5, Nomor 1, Juni 2015; ISSN 2088-7957; 139-163

Assauri, S. 2007.Teknik dan Metode Peramalan: Penerapannya dalam Dunia Ekonomi dan Usaha.Jakarta: Lembaga Penerbit FEUI

Pandji, Anoraga. 1997. Manajemen Bisnis. Jakarta: Rineka Cipta.

Kotler Philip, Amstrong. 2006. Manajemen Pemasaran Analisis, Perencanaan, Implementasi dan Kontrol. Edisi Millenium. PT. Prenhallindo. Jakarta. 